\title{
Donor support for the human rights of LGBT+
}

Laura Bolton

IDS

14 June 2021

\section{Question}

How are bilateral and multilateral donors promoting and protecting the human rights of LGBT+ people globally? Which have policies, implementation plans and programmes on LGBT+ rights? What has been the impact of the work?

\section{Contents}

1. Summary

2. Overview of donor support to LGBT+ issues in the global South and East

3. Bilateral donors

4. Multilateral donors

5. Projects

6. References

The K4D helpdesk service provides brief summaries of current research, evidence, and lessons learned. Helpdesk reports are not rigorous or systematic reviews; they are intended to provide an introduction to the most important evidence related to a research question. They draw on a rapid deskbased review of published literature and consultation with subject specialists.

Helpdesk reports are commissioned by the UK Foreign, Commonwealth, and Development Office and other Government departments, but the views and opinions expressed do not necessarily reflect those of FCDO, the UK Government, K4D or any other contributing organisation. For further information, please contact helpdesk@k4d.info. 


\section{Summary}

The bilateral donors providing the most support for LGBT+ (Lesbian, Gay, Bisexual, Transgender, +) communities in 2017-18 are the Swedish International Development Cooperation Agency (Sida), UK Department for International Development (DFID) ${ }^{1}$, The Netherlands Development Cooperation, Norwegian Agency for Development Cooperation (Norad), and the European Commission (EC).

Sida support the Swedish Federation for Lesbian, Gay, Bisexual, Transgender, Queer and Intersex Rights (RFSL) which works locally and internationally on LGBT+ rights. Sida also support the UNDP Inclusive Government Initiative and the Coalition of African Lesbians (CAL). Evaluation of past Sida projects found they had positive impacts on human resources and organisational structure for advocacy in UN fora contributing to the formulation of Agenda 2030 and the Sustainable Development Goals.

Broad aims were identified from The Netherlands Development Cooperation to promote equal rights for LGBT+ people. They work with the Equal Rights Coalition, ensuring equal rights is prioritised in international organisations, supporting local organisations, working through embassy networks, and funding LGBT+ rights projects.

It was difficult to identify how Norad have spent aid money on LGBT+ rights internationally in recent years within the scope of this review. Guidelines have been produced in 2013 and 2010 supporting Norwegian foreign and embassy work on LGBT+ rights.

It was difficult to identify EC policies and programmes outside of Europe. One briefing on LGBT+ in Africa was identified. The EC is one of the funders for the International Lesbian, Gay, Bisexual, Transgender, Queer Youth and Student Organisation (IGLYO).

USAID have a Human Rights Grant Programme which funds LGBT+ human rights work. USAID, along with Sida and other donors, fund the LGBT+ Global Human Rights Initiative. USAID have funded a number of research reports on LGBT+ rights.

Activities of the UK Department for International Development (DFID) and the Foreign Commonwealth Office (FCO), now the Foreign Commonwealth and Development Office (FCDO), are not included here as they were already known to the requester of this report.

The United Nations (UN) are doing a huge amount of work on LGBT+ rights across the organisation which there was not scope to fully explore in this report. The UN Office of the High Commissioner on Human Rights (UNOCHR) in particular are doing a lot on this theme. They publish legal obligation information, call attention to rights abuses through general assembly resolutions. They dialogue with governments, monitor violations, and support human rights treaties bodies.

The UN campaign Free and Equal encourages message sharing on social media. The UNDP support a number of regional and national programmes. Activities are also carried out on LGBT+

\footnotetext{
${ }^{1}$ Now merged with the Foreign and Commonwealth Office to become the Foreign, Commonwealth, and Development Office (FCDO)
} 
rights by UNFPA, UNODC, UNHCR, UNICEF, and UN Women. The ILO recognise LGBT+ rights and support training for employment of LGBT+ people.

The work of the World Bank in this area focuses on inclusion rather than rights. A small number of projects were identified which receive funding from bilateral and multilateral donors. These were AMSHeR, International Lesbian, Gay, Bisexual, Trans and Intersex Association (ILGA), and Stonewall.

This rapid review focused on identifying donor support for LGBT+ rights, therefore, searches were limited to general databases and donor websites, utilising non-academic and donor literature. Much of the information comes directly from websites and these are footnoted throughout the report. Little was identified in the way of impact evaluation within the scope of this report. The majority of projects found through searches were non-governmental and so not the focus of this report.

\section{Overview of donor support to LGBT+ issues in the global South and East}

\section{7-2018 Global Resources Report: Government \& Philanthropic Support for LGBTI Communities}

Global Philanthropy Project (2019)

https://globalresourcesreport.org/

Of the top ten funders for LGBT+ issues in the Global South and East ${ }^{2}$ in the two years 2017-18, four were government donors and one was a multilateral donor (see Table 1). The remaining five were foundations or intermediaries. ${ }^{3}$

Table 1: Funders of LGBT+ issues in the Global South and East in 2017-18

\begin{tabular}{|l|c|}
\hline Development Agency & Total funding (US\$) \\
\hline $\begin{array}{l}\text { Swedish International Development } \\
\text { Cooperation Agency (Sida) }\end{array}$ & $21,069,875$ \\
\hline $\begin{array}{l}\text { UK Department for International } \\
\text { Development (DFID) }\end{array}$ & $15,593,496$ \\
\hline The Netherlands Development Cooperation & $12,200,843$ \\
\hline
\end{tabular}

\footnotetext{
2 Includes (1) Asia and the Pacific; (2) Eastern Europe, Central Asia, and Russia; (3) Latin America and the Caribbean; (4) the Middle East and North Africa; and (5) Sub-Saharan Africa.
}

${ }^{3}$ Open Society Foundations, Ford Foundation, COC Netherlands, Elton John AIDS Foundation UK, and Hivos. 


\begin{tabular}{|l|c|}
\hline $\begin{array}{l}\text { Norwegian Agency for Development } \\
\text { Cooperation (Norad) }\end{array}$ & $7,789,533$ \\
\hline European Commission (EC) & $5,806,352$ \\
\hline
\end{tabular}

Source: Global Philanthropy Project, 2019, p50, licensed under CC BY-NC-SA 4.0

$38 \%$ of all LGBT+ funding for the Global South and East was awarded by donor governments and multilateral agencies. In the 5 years 2013-2018 governments and multilaterals contributed US $\$ 65,283,639$. 61 percent of all funding to the Global South and East in 2017-8 was for advancing human rights.

Issues funded include sexual and reproductive rights (7\%), gender identity rights (4\%), challenging anti-LGBT + laws $(2 \%)$, civil unions $(2 \%)$, non-discrimination protections $(2 \%)$, intersex rights $(1 \%)$, decriminalisation reforms $(<1 \%)$, migration/refugee issues $(<1 \%)$, and sex worker rights $(<1 \%)$.

This report was followed by a number of briefs published in $2021 .{ }^{4}$

\section{Bilateral donors}

\section{Swedish International Development Cooperation Agency (Sida)}

Sida support the Swedish Federation for Lesbian, Gay, Bisexual, Transgender, Queer and Intersex Rights (RFSL) ${ }^{5}$ which works locally and internationally on LGBT+ rights including crime victim support and political advocacy.

Sida supports the United Nations Development Programme (UNDP) Inclusive Governance Initiative ${ }^{6}$ aiming to improve knowledge and commitment among decision makers in Africa. The initiative also works with activists to improve their ability to influence legislation.

Sida are one of the main donors for the Coalition of African Lesbians $(C A L)^{7}$, a network of activist organisations in 10 countries in Sub-Saharan Africa.

Sida funded study on LGBT+ rights in Indonesia (Falkenberg \& Freji, 2019).

\footnotetext{
${ }^{4}$ The four briefs are hyperlinked here: LBQTI funding data, LGBTI Sex Worker funding data, The role of intermediaries in increasing resources for global LGBTI rights, How can embassies advance LGBTI rights?

${ }^{5}$ https://www.rfsl.se/en/ accessed 2.6.21

${ }^{6}$ https://www.africa.undp.org/content/rba/en/home/library/the-inclusive-governance-initiative.html accessed 2.6.21

${ }^{7}$ https://www.cal.org.za/ accessed 4.6.21
} 


\section{Impact}

An evaluation of the Sida supported RFSL projects 'LGBT Voices' and 'Rainbow Leaders' found positive contributions in progressing LGBT+ rights (Nilsson \& Rothman, 2017). The LGBT Voices project supported capacity and voice of RFSL and partners for advocacy in UN fora. The Sida support was used to enhance human resources and organisational structure to work strategically. The organisation has contributed to achievements in advocacy processes including the formulation of Agenda 2030 and the SDGs, and the preparation of the resolution in the Human Rights Council on a mandate for an independent expert on Sexual Orientation and Gender Identity Expression (SOGIE) issues.

The Rainbow Leaders training project, funded by Sida and USAID, aimed to develop capacity, inspire mobilisation and enhance visibility of LGBT+ organisations to promote SOGIE issues in local, regional, and international arenas. It consisted of 4 courses over 4 years and was attended by 120 activists from 84 different organisations in 34 countries. Feedback from participants was positive. A number of Rainbow Leaders went on to improve networking and advocacy at national levels.

\section{Netherlands Development Cooperation}

Efforts to promote equal rights for LGBT+ people worldwide are listed on the government website without detail of activities. ${ }^{8}$ These include:

- Working with countries in the Equal Rights Coalition ${ }^{9}$

- Ensuring equal rights for LGBT+ people is prioritised in international organisations such as the UN, the Organization for Security and Co-operation in Europe (OCSE), the Council of Europe (CoE) and the European Union (EU)

- Partnering with larger organisations who support local organisations

- Interacting with, and supporting LGBT+ organisations through the embassy network

- Funding projects which promote rights for LGBT+ people

Government policy and planning that was identified in this rapid review tended to focus on national and regional levels within Europe and it was difficult to identify specifics at international level.

Activities identified include:

- Direct financial support to a Nigerian Human Rights Organisation which organises in opposition to a Same-Sex Marriage Prohibition bill (Huiskes \& Reinders, 2018).

- Fighting the "Gay Propaganda" Law in Krygystan (Cook \& Viera, 2016). This was funded by the Dutch Government through civil society organisations COC Netherlands ${ }^{10}$, Labrys

\footnotetext{
${ }^{8}$ https://www.government.nl/topics/human-rights/human-rights-worldwide/equal-rights-for-lesbian-gay-bisexualand-transgender-and-intersex-Igbti accessed 4.6.21

${ }^{9} \mathrm{https}: / /$ www.gov.uk/government/collections/equal-rights-coalition accessed 4.6.21

${ }^{10} \mathrm{COC}$ originally stood for Cultuur en Ontspanningscentrum, https://www.coc.nl/engels accessed 4.6.21
} 
and Kyrgyz Indigo in Kyrgyzstan. At the time of publishing of the Cook \& Viera report, May 2016, the law had not been passed.

It was not possible to find a comprehensive list of activities within the scope of this review.

\section{The Norwegian Government}

The Norwegian Ministry of Foreign Affairs produced a 2013 guideline for the Norwegian Foreign Service on human rights and SOGI ${ }^{11}$ (Norwegian Ministry of Foreign Affairs, 2013). The guide is to show how Norway can help strengthen LGBT+ human rights efforts through foreign missions. It provides lessons on rights promotion from foreign missions and steps to take on behalf of LGBT+ persons. And an older guideline for systematising and strengthening embassy efforts (Norwegian Ministry of Foreign Affairs, 2010).

Activities identified:

- The Norwegian Embassy in Nepal has worked to challenge discriminatory practices that effect the LGBT community (Jones et al., 2015).

- Supporting LGBT+ rights in Nepal. Funding civil society organisations to work with the embassy on SOGIE issues and to work with international organisations on LGBT+ rights. (Cook \& Vieira, 2016).

Nothing on impact was found within the scope of this review.

\section{European Commission (EC)}

The European Parliament produced a briefing on LGBT+ in Africa highlighting discrimination and criminalisation (Pichon \& Kourchoudian, 2019). It outlines European Union (EU) action and European Parliament's position. In 2013 the EU adopted guidelines that national embassies of EU states take a pro-active attitude in promoting LGBT+ rights. Delegations and member state embassies focus on decriminalisation, combatting discriminatory laws and practices, and supporting LGBT+ human rights defenders.

The EC funds the International Lesbian, Gay, Bisexual, Transgender, Queer Youth and Student Organisation (IGLYO). ${ }^{12}$ Also funded by Council of Europe, European Youth Foundation, and the Government of the Netherlands.

Rapid searching produced many results on rights work within the EU but it was difficult to find details of international work within the scope of this review.

\footnotetext{
${ }^{11}$ Sexual orientation and gender identity. The acronym SOGIE was used earlier in this report but the Norwegian Government use SOGI and similarly in the later UN section. The report uses the acronym according to the source.

12 https://www.iglyo.com/ accessed 10.6.21
} 


\section{United States Agency for International Development (USAID)}

\section{Global Human Rights Initiative (GHRI)}

USAID funds the Multi-Donor LGBTQI+ ${ }^{13}$ GHRI with Sida, Global Affairs Canada, and private sector entities (USAID, n.d.). It is a five-year (2019-24) public-private partnership leveraging financial and technical contributions from multiple partners to support local LGBT+ organisations, global research, behaviour change communication capacity building, and emergency response.

\section{Human Rights Grants Program}

USAID's Human Rights Grants Program provides funds for LGBT+ human rights challenge response. ${ }^{14}$

\section{Research reports}

USAID have funded a number of research reports supporting LGBT+ rights and inclusion. Including:

- The LGBT Rights Acceptance Index measuring social acceptance over time in 174 countries. ${ }^{15}$

- The Global Barometer of Gay Rights and the Global Barometer of Transgender Rights which measure and rank persecution and protection of LGBT+ people in 203 countries over time. ${ }^{16}$

- Publications showing the negative links between LGBT+ discrimination and economic development. ${ }^{17}$

\section{Impact}

One impact evaluation was identified from a joint USAID and UNDP project, Support to Strengthen Gay, Lesbian, Bisexual, and Transgender Civil Society Organizations in Vietnam (UNDP, 2016). The project aimed to strengthen Vietnamese Civil Society Organisations to reduce stigma, prevent discrimination, and review laws. The research and capacity building

\footnotetext{
${ }^{13}$ Additions to this acronym Q - queer, and I - intersex

14

https://www.usaid.gov/sites/default/files/documents/1866/One\%20Pager\%20Human\%20Rights\%20Grants\%20Pr ogram\%20\%28HRGP\%29\%20Overview.pdf accessed 3.6.21

${ }^{15}$ https://williamsinstitute.law.ucla.edu/publications/global-acceptance-index-lgbt/ accessed 3.6.21

${ }^{16}$ https://www.fandmglobalbarometers.org/ accessed 3.6.21

17 The Relationship Between LGBT Inclusion and Economic Development: Emerging Economies https://williamsinstitute.law.ucla.edu/publications/lgbt-inclusion-economic-dev/; The Economic Cost of LGBT Stigma and Discrimination in South Africa(link is external) https://williamsinstitute.law.ucla.edu/publications/costdiscrim-so-africa/; and, Stress, Health, and Well-Being of LGBT People in Colombia: Results from a National Survey https://williamsinstitute.law.ucla.edu/publications/lgbt-people-colombia/
} 
carried out by the project was found to have contributed directly to improvements in the legal and human rights status of LGBT+ people in Vietnam.

\section{Multilateral donors}

\section{United Nations (UN)}

The UN Office of the High Commissioner on Human Rights (UNOHCHR) publish information on the legal obligations of states to protect the human rights of LGBT+ people. ${ }^{18}$ This includes protection of individuals from homophobic and transphobic violence, prevention of degrading treatment, obligation to repeal laws criminalising homosexuality, prohibition of discrimination, and safeguarding freedom of expression (UNOHCHR, 2019).

The UN general assembly through resolutions ${ }^{19}$ call attention to incidents such as the killing of persons on the basis of SOGI and violence towards LGBT+ people.

Ongoing activities of $\mathrm{OHCHR}$ include dialogue with governments, monitoring human rights violations, public advocacy ${ }^{20}$, working with UN partners, supporting fact finding, supporting human rights treaties bodies ${ }^{21}$, and a review of the human rights records of UN member states.

The UN campaign Free and Equal launched in 2013 running events, posting information and encouraging sharing through social media.

The UN Development Programme (UNDP) have regional programmes - Being LGBTI22 and SOGIESC ${ }^{23}$ and rights. In Africa, UNDP supported the drafting of LGBT+ rights assessment reports for a number of African countries. In Cameroon, the report was used to inform National Strategic Plans. The UNDP produce knowledge products such as human rights and inclusion handbooks and legal reviews. Being LGBTI is also supported by USAID.

The UN Population Fund (UNFPA) collaborate with and support UN advocacy bodies including the LGBTI Equal Rights Coalition. The UN Office on Drugs and Crime (UNODC) provide guidance, training and advice for prison management where LGBT+ people are in the prison population (UN, 2019). The UN High Commissioner for Refugees (UNHCR) works on international protection and shares legal, policy and operational guidance for policy-makers

\footnotetext{
${ }^{18} \mathrm{https}: / /$ www.ohchr.org/en/issues/discrimination/pages/lgbt.aspx accessed 9.6.21

${ }^{19}$ https://www.ohchr.org/EN/Issues/Discrimination/Pages/LGBTUNResolutions.aspx accessed 9.6.21

20 Speeches and statements https://www.ohchr.org/EN/Issues/Discrimination/Pages/LGBTUNResolutions.aspx accessed 9.6.21; newspaper articles

https://www.ohchr.org/EN/Issues/Discrimination/Pages/LGBTOpinioneditorials.aspx accessed 9.6.21, video messages https://www.ohchr.org/EN/Issues/Discrimination/Pages/LGBTVideos.aspx accessed 9.6.21, and fact sheets https://www.ohchr.org/EN/Issues/Discrimination/Pages/LGBTFactSheets.aspx accessed 9.6.21.

${ }^{21}$ https://www.ohchr.org/EN/HRBodies/Pages/Overview.aspx accessed 9.6.21

22 LGBTI (Lesbian, gay, bisexual, transgender, intersex)

${ }^{23}$ SOGIESC (Sexual orientation, gender identity, gender expression and sex characteristics)
} 
working with LGBT+ refugees. UN Child's Fund (UNICEF) address issues affecting LGBT+ children and parents of LGBT+ children.

United Nations Entity for Gender Equality and the Empowerment of Women (UN Women) "works across its normative, UN coordination and operational roles to develop programming and advocacy that integrate LGBTI people's rights and perspectives" (UN, 2019, p12). UN Women developed internal guidance notes on SOGI rights to integrate LGBT+ considerations into their work. UN Women integrated LGBT+ rights into advocacy work in a number of forums including the $63^{\text {rd }}$ session of the Commission on the Status of Women in March 2019. UN Women also collaborate with a number of Permanent Missions and participate in various UN working groups to ensure the inclusion of LGBT+ voices.

The International Labour Organisation (ILO) had a research project to support LGBT+ rights in work called Gender Identity and Sexual Orientation: Promoting Rights, Diversity and Equality in the World of Work. ${ }^{24}$ The project conducted research in a number of countries identifying gaps in legal provisions and workers terms (ILO, 2013). It also identified 'good practice' workplaces. Smaller projects have worked to train LGBT+ people to prepare them for work for example the project "Employability of Trans People - Kitchen and Voice". ${ }^{25}$ The International Organisation for Migration aims to combat discrimination and abuse against LGBT+ migrants and provide training on working with LGBT+ migrants (UNOHCHR, 2019).

\section{World Bank}

The World Bank outlook on LGBT+ uses the language of inclusion rather than rights. ${ }^{26}$

"The World Bank approaches SOGI inclusion through our commitments on gender equality and social inclusion."27

The World Bank have produced studies on the economic costs of stigma and exclusion.

SOGI issues are included in strategic documents such as Systematic Country Diagnostics and Country Partnership Frameworks. There is a SOGI taskforce ${ }^{28}$ pushing the inclusion agenda at the World Bank and a designated SOGI adviser. ${ }^{29}$

The three areas of focus for the World Bank are:

\footnotetext{
${ }^{24}$ http://www.ilo.org/gender/Informationresources/Publications/WCMS_481575/lang--en/index.htm. Accessed 9.6 .21

${ }^{25}$ https://www.ilo.org/global/about-the-ilo/mission-and-objectives/features/WCMS_638927/lang--en/index.htm accessed 10.6.21

${ }^{26}$ https://www.worldbank.org/en/topic/sexual-orientation-and-gender-identity\#1 accessed 8.6.21

27 https://www.worldbank.org/en/topic/sexual-orientation-and-gender-identity\#2 accessed 8.6.21

${ }^{28} \mathrm{https}: / /$ blogs.worldbank.org/team/sogi-task-force accessed 8.6.21

${ }^{29}$ https://www.worldbank.org/en/news/press-release/2016/10/27/world-bank-announces-new-advisor-on-sexualorientation-and-gender-identity-issues accessed 8.6.21
} 
1) Training to sensitise staff and clients about SOGI issues.

2) Data generation to show development outcomes for LGBT+ people.

3) Piloting initiatives to improve the access of LGBT+ to markets, services, and spaces. And supporting project design to minimise SOGI-based discrimination.

The World Bank Environmental and Social Framework ${ }^{30}$ is committed to identifying and minimising LGBT+ in project design.

\section{Projects}

Rapid searches identified many projects and programmes which are independent nongovernmental organisations and so not the focus of this report. It was difficult to identify donor information on some LGTB+ rights websites.

\section{AMSHeR}

AMSHeR ${ }^{31}$ works to contribute to better lives for people of diverse sexual orientations advocating for human rights principles as the basis of development programming. ${ }^{32}$ They aim to strengthen capacity and collaboration amongst LGBT+ civil society organisations in Africa to champion health, human rights, social justice and development.

The project receives funding from public and private donors. The public donors include the EC, UNDP, UNAIDS, and the UN Department of Political Affairs.

\section{International Lesbian, Gay, Bisexual, Trans and Intersex Association (ILGA)}

ILGA Europe is supported by the EC and work includes international support, such as involvement in the Dignity for All: LGBTI Assistance Programme. ${ }^{33}$ The programme provides emergency funds and support to human rights defenders working for LGBT+ human rights.

\section{Stonewall}

Stonewall have an international programme empowering LGBT+ rights defenders to campaign for change in their countries. ${ }^{34}$ It's listed funders include $\mathrm{FCO}^{35}$, the Scottish Government, and the Welsh Government, as well as private trusts and foundations.

\footnotetext{
30 https://www.worldbank.org/en/projects-operations/environmental-and-social-framework accessed 8.6.21

31 It was not possible to find out what this name stands for.

32 https://amsher.org/who-we-are/ accessed 10.6.21

${ }^{33}$ https://freedomhouse.org/programs/LGBTI-assistance accessed 10.6.21

${ }^{34}$ https://www.stonewall.org.uk/our-work/campaigns/campaigning-global-lgbt-equality accessed 10.6.21

${ }^{35}$ It is listed on the website as FCO rather than FCDO so unknown as to the current funding status
} 


\section{References}

Cook, B., \& Vieira, B. (2016). The Road to Successful Partnerships: How governments in the Global North can effectively partner with intermediary organizations to support LGBTI communities in the Global South and East. Global Philanthropy Project. https://globalphilanthropyproject.org/wp-content/uploads/2016/09/The-Road-toSuccessful-Partnerships-FINAL-7.7.16.pdf

DFID (2016). DFID's approach on LGB\&T rights. https://assets.publishing.service.gov.uk/government/uploads/system/uploads/attachment _data/file/498868/LGBT-DFID-Approach-paper.pdf

DFID (2019.) UK Aid Connect: Terms of Reference Addressing Lesbian, Gay and Bisexual and Transgender Inclusion.

https://assets.publishing.service.gov.uk/media/5968a106e5274a0a69000194/Terms-ofReference-Addressing-Lesbian-Gay-and-Bisexual-and-Transgender-Inclusion.pdf

Falkenberg, A. \& Freji, E. (2019). "LGBT-rights in decline" - a qualitative study of the experiences of LGBT-people in Indonesia. https://www.divaportal.org/smash/get/diva2:1487733/FULLTEXT01.pdf

Global Philanthropy Project (2019). 2017-2018 Global Resources Report: Government \& Philanthropic Support for LGBTI Communities. https://globalresourcesreport.org/

Huiskes, M. \& Reinders, J. (2018). Addressing Sexual and Gender Diversity in Dutch development cooperation. A report of the mapping by Share-Net Netherlands on addressing sexual and gender diversity by Dutch NGOs, universities, and Dutch ministries in development cooperation. http://share-netinternational.org/wpcontent/uploads/2018/03/Addressing-Sexual-and-Gender-Diversity-in-DutchDevelopment-Cooperation-Final-Report-.pdf

ILO (2013). Discrimination at work on the basis of sexual orientation and gender identity: Results of pilot research. http://www.ilo.org/wcmsp5/groups/public/---ed_norm/--relconf/documents/meetingdocument/wcms_221728.pdf

Jones, N., Tvedten, I., Arbulú, A., Pereznieto, P., Lindström, J. \& Norbakk, M. Evaluation of Norway's support to women's rights and gender equality in development cooperation. Norad Evaluation Department. https://www.oecd.org/derec/norway/Evaluation-ofnorways-support-to-womens-rights-and-gender-equality-in-development-cooperation.pdf

Nilsson, A. \& Rothman, J. (2017). Evaluation of the Sida supported RFSL projects "LGBT Voices" and "Rainbow Leaders". https://publikationer.sida.se/contentassets/a09863bdac41467ea541a12e2160caf5/22051 .pdf

Norwegian Ministry of Foreign Affairs (2013). Human Rights, Sexual Orientation and Gender Identity. Guidelines for the Norwegian Foreign Service. https://www.regjeringen.no/contentassets/b7384abb48db487885e216bf53d30a3c/lgbt_g uidelines.pdf 
Norwegian Ministry of Foreign Affairs (2010). Promoting the human rights of LGBT - lesbian, gay, bisexual and transgender - people Guidelines for systematising and strengthening embassy efforts.

https://www.regjeringen.no/globalassets/upload/ud/vedlegg/menneskerettigheter/guidelin es_hr_lgbt.pdf

Pichon, E. \& Kourchoudian, G. (2019). LGBTI in Africa Widespread discrimination against people with non-conforming sexual orientations and gender identities. European Parliament. https://www.europarl.europa.eu/RegData/etudes/BRIE/2019/637949/EPRS_BRI(2019)63 7949_EN.pdf

UN (2019). The Role of the United Nations in Combatting Discrimination and Violence against Lesbian, Gay, Bisexual, Transgender and Intersex People A Programmatic Overview. https://www.ohchr.org/Documents/Issues/Discrimination/LGBT/UN_LGBTI_summary_20 19.pdf

UNDP (2016). Final Evaluation Report: Support to Strengthen Lesbian, Gay, Bisexual and Transgender (LGBT) CSOs in Vietnam. UNDP Evaluation Resource Centre. https://erc.undp.org/evaluation/documents/download/9710

UNOCHR (2019). Born free and equal. Sexual orientation, gender identity and sex characteristics in international human rights law. https://www.ohchr.org/Documents/Publications/Born_Free_and_Equal_WEB.pdf

USAID (n.d.). The Multi-donor LGBTI Global Human Rights Initiative. https://www.usaid.gov/LGBTQI/LGBTQI-Programs 


\section{Suggested citation}

Bolton, L. (2021). Donor support for the human rights of LGBT+. K4D Helpdesk Report. Brighton, UK: Institute of Development Studies. DOI: 10.19088/K4D.2021.100

\section{About this report}

This report is based on six days of desk-based research. The K4D research helpdesk provides rapid syntheses of a selection of recent relevant literature and international expert thinking in response to specific questions relating to international development. For any enquiries, contact helpdesk@k4d.info.

K4D services are provided by a consortium of leading organisations working in international development, led by the Institute of Development Studies (IDS), with Education Development Trust, Itad, University of Leeds Nuffield Centre for International Health and Development, Liverpool School of Tropical Medicine (LSTM), University of Birmingham International Development Department (IDD) and the University of Manchester Humanitarian and Conflict Response Institute (HCRI).

This report was prepared for the UK Government's Foreign, Commonwealth and Development Office ( $F C D O)$ and its partners in support of pro-poor programmes. Except where otherwise stated, it is licensed for non-commercial purposes under the terms of the Open Government License v3.0. K4D cannot be held responsible for errors, omissions or any consequences arising from the use of information contained in this report. Any views and opinions expressed do not necessarily reflect those of FCDO, K4D or any other contributing organisation.

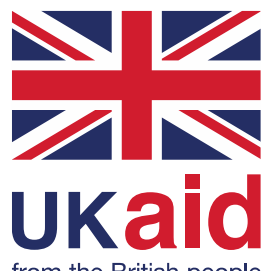

(c) Crown copyright 2021. 